\title{
The Impact of Gender on Students' Choice of a Bachelor's Degree from International Degree Programmes Offered in Sri Lanka: A Case Study
}

\author{
K.A. Vidyanjalie Abeygunawardena* \\ Faculty of Education, University of Colombo, Sri Lanka
}

\begin{abstract}
As the National university intake in Sri Lanka has become progressively competitive over the years, the International Degree Programmes (IDPs) of top-ranked foreign universities emerged in the domestic market to cater to the rising demand for university-level education. Alternatively, those IDPs are mostly offered with higher optionality and flexibility to attract potential students to increase student enrollment. Therefore, the study mainly discusses how the popularity of IDPs varied among Sri Lankan students within the period from 2011 to 2014. However, the study aims to identify how students select a Bachelor's degree from IDP based on the subject stream completed for their advanced level and further to identify any significant differences in the decision making criteria gender-wise. Therefore, 694 students (120 in the year 2011, 145 in the year 2012, 187 in the year 2013, 242 in the year 2014) selected from Economics, Management and Social science related Bachelor's degrees in an IDP and data collected by official documents of the private higher educational institute. The Chi-square test of association was conducted gender-wise to identify the relationship between the subject stream followed for advanced level and the Bachelor's degree selected. Later, the significant differences have compared within the period from 2011 to 2014. The results indicated that boys show a positive trend in using the optionality where they choose the Bachelor's Degree independently from the subject stream completed in advanced level. Alternatively, the decision-making criteria of girls showed differences contrary to boys. Hence, the behaviour of students' need to be researched and verified in current years to identify any significant impact on the decision-making criteria due to the gender of the student.
\end{abstract}

Keywords: Bachelor's degree, Decision- making process, Gender, International degree programmes

\section{Introduction}

Access to higher education is the ultimate dream in many young minds. The selection and allocation of students to national universities in Sri Lanka is governed by the University Grants Commission (UGC) which was established under the University Act No 16 in 1978. It depends on the student's performance at the General Certificate of Education (GCE) Advanced level examination in Sri Lanka. Indeed, the selection mainly depends on the $\mathrm{Z}$ score of the student and the 'cut off' mark of the degrees which calculate by the Commissioner General of Examination (UGC, 2017). The drawback in the existing examination system in Advanced Level is the stress caused to students because of the competitive nature of it. Additionally, National University intake in Sri Lanka has become progressively competitive over the years due to the limited number of placements available and the selection procedure under the free education policy. Of the 149,489 students who were eligible for National university admission from GCE Advanced level examination in 2014/2015, only 17\% have admitted to National universities (UGC, 2016). According to the population census in 2012, only $4 \%$ of the age 25 years and above population have a Bachelor's degree level qualification in Sri Lanka. Therefore, it has become challenging for Sri Lankan students to pursue a Bachelor's degree in catering to the demands of the future job market. It has been identifying that many students who fail to enter National Universities and students who complete the Advanced level in British curriculum at private or International schools are presumed to continue their university-level education at a foreign university in an overseas country based on their affordability (Sunday Times, 2011). But foreign university education in an overseas country is very costly and parents concerned about their children's safety when sending them abroad due to natural disasters in several parts of the world, 
terrorism and political stability in many countries (Daily mirror, 2017). Further, various adverse effects may occur since students have to leave their families and study in a novel and challenging environment (Sunday Times, 2011). As a result, most of the students have been increasingly seeking alternative educational options in the domestic market. However, the students' choice in selecting a preferred Bachelor's degree is further limited in National universities and students should follow some pre-requite subjects under a particular subject stream which have been listed by UGC under each Bachelor's degree.

However, the governance of the higher education system throughout the world has changed considerably in recent years. Internalization is a term being used to discuss the International dimensions of higher education, and more widely post-secondary education (Knight, 2007). As a result of Internationalization in education, International degree programmes have emerged in several countries where degree programmes move from one country to another instead of students. Alternatively, it has forecasted that the demand for International education will be 7.2 million in 2025 (Knight, 2012) and foreign universities may have the challenge to fulfill the requirement. Hence most of the foreign universities which hold higher global rank offer their Bachelor's degrees through International degree programmes to International students, parallel to their local students. Consequently, International degree programmes emerged in Sri Lanka affiliated with private higher educational Institutes to cater to the need of university-level education due to the challenges in the national university admission.

In present conditions, the International degree programmes offered in Sri Lanka are very popular among students due to the optionality and flexibility designed with the Bachelor's degree programmes (Abeygunawardena, 2018). Indeed, it has become strategically complicated to select the Bachelor's degree based on the modules and study majors from a large number of subjects listed in the prospectus of the foreign university Abeygunawardena, 2018). Moreover, students are allowed to choose most of their preferred Bachelor's degree irrespective of the subject stream done for Advanced level examination since the admission for International degree programmes is with the minimum requirements listed under each Bachelor's degree. Thereby, the knowledge of pre-requisite subjects may not be essential at the stage of enrollment since most of the Bachelor's degree in the International degree programmes are design with the pre-requisite knowledge. As the number of demographic, economic, social and psychological factors influences on the Bachelor's degree selection, the decision-making process is complex and multifactorial. Alternatively, the difference between 'correct' and 'wrong' choices may be difficult to identify at an initial stage (Ozga \& Sukhandan, 1997), and suboptimal decisions at the point of entry could increase the failure rate (Yorke, 1999). Moreover, Ozga and Sukhandan (1997) opine that sub-optimal choices of students would impact negatively on their motivation and academic success, which may lead to student dissatisfaction. Hence, it is of vital importance to study about the student's choice in selecting a Bachelor's degree and the studies conducted by Hearn (1984), and Tierney (1983) analysed students' behaviour as consumers in the private higher education marketplace.

However, the process of decision making is one of the most complex mechanisms of human thinking and Orasanu \& Connolly (1993) defined it as a series of cognitive operations performed consciously, which include the elements from the environment in a specific time and place. Narayan \& Corcoran (1997) consider decision making as the interaction between a problem that needs to be solved (select a Bachelor's degree) and a person who wishes to solve it (student) within a specific environment. According to Halpern (1997), students should follow several steps to arrive at a decision. Firstly they need to identify the necessity of making the decision and the goals to be achieved. Secondly, generate alternatives which lead towards the proposed goals. Finally, evaluate all possible alternatives generated towards selecting the best one. However, gender is an important characteristic which can be used to compare the differences in human thought processes and behaviour (Abeygunawardena, 2019). It has identified that boys and girls do not behave in the same way when making educational decisions and the importance placed for the influential factors are different based on the gender of the students (Abeygunawardena, 2019). Therefore, students' choice in selecting a Bachelor's degree can consider as a long-term investment decision and students have become consumerists due to the cost of obtaining 
a Bachelor's degree under International degree programmes (Briggs, 2006). Hence it is vital of importance to investigate how students have selected the Bachelor's degree based on their subject streams of Advanced level and any variation of the selection criteria based on the gender for several years.

\section{Literature Review}

\section{Decision making models}

According to Neoclassical economics, students select the preferred Bachelor's degree out of various Bachelor's degrees offer in International degree programmes to maximise their long-term satisfaction (Abeygunawardena, 2018). However, numerous theoretical models were suggested to describe various processes by which a postsecondary student can follow when selecting a Bachelor's degree from private higher educational institutes including all influential factors which influence students' intention to pursue university-level education. According to Fernandez (2010), there are three theoretical choice models such as economic models, sociological models and combined models. Many studies on 'student decision making' rely on economics, sociological and combined models to examine factors of students' choice (Hearn, 1984; Jackson, 1978; Tierney, 1983; Somers et al., 2006). Under economic models, individuals are assumed to act rationally in ways that maximise their utility based on their personal preferences (poo et al., 2012). The underlying assumption of the economic models is that students will select a particular Bachelor's degree or a private higher educational institute if the benefit of that choice exceeds the perceived benefits of other alternatives (Poo et al., 2012). Furthermore, the economic model assumes that, even when the expected benefits and costs are the same, two individuals may make different choices when selecting a Bachelor's degree or a private higher educational institute (Fernandez, 2010). The sociological models are also known as status-attainment models. It concentrates on the importance of student's background characteristics and socioeconomic status as factors affecting students' choice of higher education. The combined model incorporates the characteristics of the economic and status-attainment models to describe students' choice process (McDonough, 1997; Clark \& Wiebe, 1993). Indeed the combined models allow a considerable amount of analytical power since they combine sociological perspective with rational decision making (Hamrick \& Hossler, 1996). According to Hossler et al.(1999), the combined models can be explained under four major models: the Jackson model; Chapman model; Hanson and Litten model; Hossler and Gallagher model.

\section{Decision making theories}

Every day people use to make decisions and, the entire decision-making process affects by personal and environmental variables (Abeygunawardena, 2019). According to Cannon-Bowers, Salas \& Pruitt (1996), the essential traits of a decision depends on three variables. The first factor is the task factors associated with the nature of the decision such as the uncertainty involved in each alternative, time and money pressure, quantity and quality of the information, expected goals, and possible consequences of the decisions. The second factor is the internal decision maker factors such as motivation, emotions, exhaustive information processing, experience and regulation of the decision-process stages. The third factor is the environmental factors such as social influence, coercion of close persons and work demands, although they are not a direct part of the decision itself. However, the theories related to decision-making grouped into normative and descriptive perspective (as cited in Maria et al., 2007). The normative perspective explains the choice of individuals who are behaving rationally in a task that requires decision making and using statistical models to predict the subjects' responses from the information provided about each alternative. The descriptive perspective explains how individuals take decision judgment in real due to the psychological processes, task and environmental factors. These two viewpoints are different from each other based on the way they define the 'decision-maker'. The normative viewpoint confers an 'unlimited' processing capacity on decision makers that allows them to examine the possible alternatives exhaustively and choose the best (as cited in Maria et al., 2007). The descriptive perspective grants limited processing capacity that often leads decision makers' to make mistakes when considering complex and dynamics 
tasks although they tend to choose options that satisfy them (as cited in Maria et al., 2007). At present, the naturalistic theory as a branch of descriptive perspectives uses to investigate human decisions in the real world and the factors that affect them (as cited in Maria et al., 2007). The naturalistic theory explains the impact of a student's personal, academic, professional or social life on their choice (as cited in Maria et al., 2007). Indeed, the naturalistic approach to decisions tries to show that people can make the right decision without having to perform sophisticated calculations. It emphasizes to use the experience to recognize the decision problem as similar to previous other ones and to evaluate all the variables that affect each one of its phases.

\section{Gender impact on decision making}

As with other psychological phenomena, sex is among the variables that affect decision making or an aspect that allows establishing individual differences. However, the fact is that our decisions are affected by our beliefs about the characteristics that differentiate the sexes, although these beliefs create based on questionable criteria. The study conducted by Maria et al. (2007) in the USA confirmed that women are more concerned with uncertainty and doubts, the dynamics that are involved in the decision, time and money and the consequences that may derive from the decision. Women are more aware of the constraints that the setting and close persons put on them, and place more importance to their emotions in the decision-making process (Maria et al., 2007). Conversely, men assign more importance to the analysis of the information required to carry out the decision, expected outcome and the purposes of the decision (Maria et al., 2007). They are motivated during the decisionmaking process and feel more intensely the pressure from all the work-related aspects (Maria et al., 2007). As stated by Maria et al. (2007) in the same study, there are no sex differences in cognition and self-regulation. Consequently, both men and women carefully process information, retrieve the relevant decision-related data from their memories, categorize the data if they are diverse, think logically about the alternatives, predict results, evaluate the consequences, solve the problems posed by the situation and monitor all the decision stages equally. Hence it is significant to identify any gender differences in selecting a Bachelor's degree due to the flexibility and optionality offer in International degree programmes. Moreover, human behaviour is influenced by environmental stimuli which are determined by personal factors: beliefs; judgments; experiences (Bandura, 1986). As concluded by Maria et al. (2007), cognitive, behavioural and environmental factors affect the human behaviour conjointly in different ways which depend on the situation and the individual.

The students' choice in selecting a Bachelor's degree is an investment decision for the student's future endeavours and, they behave as consumers within the decision making the process. It appears that the students' choice criteria in selecting a Bachelor's degree in various disciplines and an Institution have widely researched in several countries. However, research studies related to International Bachelor's degree programmes are minimal globally and, it has not been researched in Sri Lanka since it is a newly emerging field. Indeed it is advantageous to overview the behaviour of students' when selecting the preferred Bachelor's degree from International degree programmes due to the optionality offered than national universities in Sri Lanka. Alternatively, parental involvement impact significantly on students' choice in which they share their experiences, interest and future opportunities in career choices (Pagliarulo, 2004). Therefore, the students' choice may be a collective decision of the student and the parent, yet it is questionable whether they would use the optionality properly as stated. Hence, the study mainly focuses on how far students' have used the optionality for their selection and to identify any behavioural patterns of students when selecting the Bachelor's degree within the period from 2011 to 2014.

\section{Research Questions}

The research addresses three key questions:

1. What is the relationship between the subject stream followed in Advanced level and the choice of a Bachelor's degree to pursue university-level education? 
2. Is there any significant gender differences in selecting a Bachelor's degree from International degree programmes within the specified year period from 2011 to 2014 ?

\section{Research Methodology}

A case study was planned to achieve the research questions since the students' behaviour should be monitored periodically. The private higher education institute has selected based on the recognition and experience in conducting the International degree programmes in Sri Lanka and official records of the private higher educational institutions referred to collect data. Secondary data gathered by official documents of 694 undergraduates of Economics, Management and Social Science related Bachelor's degrees offered through International degree programmes in the selected private higher educational institute within a period of 4 years from 2011 to 2014. The chi-square test of association conducted for the sample listed in table 1 annually to identify the relationship between the Bachelor's degree chosen and the subject stream followed in Advanced level.

Table 1 Sample of the study

\begin{tabular}{|c|c|c|c|c|c|c|c|}
\hline \multirow{3}{*}{ Academic Year } & \multicolumn{6}{|c|}{ Types of Bachelor's Degree } & \multirow{3}{*}{ Total } \\
\hline & \multicolumn{2}{|c|}{ Economics } & \multicolumn{2}{|c|}{ Management } & \multicolumn{2}{|c|}{ Social Sciences } & \\
\hline & Boys & Girls & Boys & Girls & Boys & Girls & \\
\hline 2011 & 32 & 11 & 36 & 9 & 12 & 20 & 120 \\
\hline 2012 & 32 & 22 & 39 & 21 & 19 & 12 & 145 \\
\hline 2013 & 45 & 31 & 50 & 26 & 18 & 17 & 187 \\
\hline 2014 & 46 & 41 & 45 & 43 & 39 & 28 & 242 \\
\hline Total & 155 & 105 & 170 & 99 & 88 & 77 & 694 \\
\hline
\end{tabular}

The chi-square test of association was conducted to identify the relationship between two categorical variables such as the type of the Bachelor's degree selected and the subject stream completed in Advanced level. The hypotheses listed below were tested using SPSS 20.

H_(01 23 4 $)$ :There is no association between the subject stream done in Advanced level and the Bachelor's degree selected by the students entered into International degree programme in 2011, 2012, 2013, 2014.

H_11 :There is an association between the subject stream done in Advanced level and the Bachelor's degree selected by the students entered into International degree programme in 2011.

H_12 :There is an association between the subject stream done in Advanced level and the Bachelor's degree selected by the students entered into International degree programme in 2012.

H_13 :There is an association between the subject stream done in Advanced level and the Bachelor's degree selected by the students entered into International degree programme in 2013.

H_14 :There is an association between the subject stream done in Advanced level and the Bachelor's degree selected by the students entered into International degree programme in 2014.

\section{Data Analyses and Discussion}

The chi-square test of association conducted for the students (80 boys and 40 girls) enrolled for International degree programmes in the year 2011 to identify whether the relationship between the selected Bachelor's degree and their Advanced level stream are independent or not. The 3X3 contingency table used for two categorical variables (types of the Bachelor's degree and the Advanced level stream) and results compared gender-wise. The SPSS output in table 2 below indicates that more than $20 \%$ of the cells have expected count less than 5 for 
both boys and girls. According to Yates, Moore \& McCabe (1999), the test condition for the contingency tables more than 2X2 follows that "No more than $20 \%$ of the expected counts are less than 5 and all individual expected counts are 1 or greater". Therefore, test conditions for the year 2011 are invalid for the chi-square test represented in table 2. Consequently, the test results are not significant to conclude about the hypothesis and the data set refined to increase the validity of the chi-square test condition. Alternatively, the test results for the entire batch of 2011 is significant with valid chi-square test conditions and rejects the null hypothesis. Therefore, it highlights the relationship between the two categorical variables is not independent. Hence, it confirms that the overall students in 2011 batch had selected their Bachelor's degree based on their Advanced level stream. Indeed it highlights a significant impact on the decision-making process based on gender.

Table 2 Pearson Chi-Square test results for the 2011 (Source: SPSS output)

\begin{tabular}{lllll}
\hline 2011 Batch & No of cases & Value & $\begin{array}{l}\text { Degrees of } \\
\text { Freedom }\end{array}$ & $\begin{array}{l}\text { Significance }(2 \\
\text { sided) }\end{array}$ \\
\hline Boys & 80 & 9.961 (c) & 4 & 0.041 \\
\hline Girls & 40 & $42.573(\mathrm{~b})$ & 4 & 0.000 \\
\hline Total & 120 & $44.341(\mathrm{a})$ & 4 & 0.000 \\
\hline
\end{tabular}

(a) 0 cells $(0 \%)$ have expected count less than 5 . The minimum expected count is 5.33

(b) 5 cells $(55.6 \%)$ have expected count less than 5 . The minimum expected count is 0.23

(c) 4 cells $(44.4 \%)$ have expected countless than 5 . The minimum expected count is 1.20

When reviewing the data set for further analysis, it has noticed that boys from science stream have selected only the Economics and Management related Bachelor's degrees. Therefore it highlights that boys from the science stream have selected the Bachelor's degree based on their advanced level knowledge and not used the optionality since none have enrolled for social science related Bachelor's degrees. Alternatively, girls from science stream used the optionality and enrolled only for Social Science related Bachelor's degrees with no prerequisite knowledge. Consequently, all students in the data set who followed Science stream have removed and the Chi-square test of association conducted for 72 boys and 20 girls. The test results are in table 3 below.

Table 3 Pearson Chi-Square test results for the 2011-refined data set (Source: SPSS output)

\begin{tabular}{llccc}
\hline 2011 Batch & No of cases & Value & $\begin{array}{l}\text { Degrees of } \\
\text { Freedom }\end{array}$ & $\begin{array}{l}\text { Significance }(2 \\
\text { sided) }\end{array}$ \\
\hline Boys & 72 & $7.689(\mathrm{c})$ & 2 & 0.021 \\
\hline Girls & 20 & $1.287(\mathrm{~b})$ & 1 & 0.257 \\
\hline Total & 92 & $11.388(\mathrm{a})$ & 2 & 0.003 \\
\hline
\end{tabular}

(a) 1 cells $(16.7 \%)$ have expected count less than 5 . The minimum expected count is 2.61

(b) 2 cells $(50 \% \%)$ have expected countless than 5 . The minimum expected count is 0.45

(c) 1 cells $(16.7 \%)$ have expected count less than 5 . The minimum expected count is .17

According to table 3, the Chi-square test condition fails for girls as 2 cells (50\%) have expected count less than 5. In the refined data set, girls from Commerce stream have selected Economics and Management related Bachelor's degrees, and Mathematics stream students have selected only Management related Bachelor's degrees. Therefore, girls from mathematics and commerce streams have not used the optionality when selecting Bachelor's degree because they have not enrolled for social science related Bachelor's degrees. However, test conditions are invalid to check the Chi-square test of independence. Subsequently, test conditions are valid for boys to check the hypothesis under the chi-square test since it has noted that only '1 cell (16.7\%) has the 'Expected count' less than 5'. As p-value of the chi-square test is highly significant at the 5\% significance level, it confirms to reject the null hypothesis. Therefore, it has indicated that there is an association between the subject stream done for advanced level and the type of the Bachelor's degree selected for boys. Hence boys have 
not used the optionality offered by the International degree programme when selecting the preferred Bachelor's degree, which is different for girls' behaviour.

The same analysis conducted for other years and same procedure implemented by checking the validity of the test condition, retest the refined dataset. The below tables display a comprehensive summary of the data analysis within the years from 2012 to 2014 .

Table $4 \quad$ Summary of Pearson Chi-Square test results for the year 2012 (Source: SPSS output)

\begin{tabular}{lll}
\hline Academic year -2012 & Boys & Girls \\
\hline Sample size - entire data set & 90 & 55 \\
\hline Pearson's Chi-Square value & 3.848 & 15.296 \\
\hline P value & $0.427(42.7 \%)$ & 0.00 \\
\hline $\begin{array}{l}\text { No. of cells (\%) whose expected } \\
\text { count is less than 5 }\end{array}$ & 4 cells $(44.4 \%)$ & 4 cells $(44.4 \%)$ \\
\hline Validity of the test condition & & Not valid \\
\hline Decision taken to continue the analysis & Science stream removed & Science stream removed \\
\hline Sample size (for refined data set) & 83 & 50 \\
\hline Pearson's Chi-Square value & 1.314 & 4.373 \\
\hline P value & $0.519(51.9 \%)$ & $0.112(11.2 \%)$ \\
\hline $\begin{array}{l}\text { No. of cells (\%) whose expected } \\
\text { count is less than 5 }\end{array}$ & 0 cells $(0 \%)$ & 1 cell $(16.7 \%)$ \\
\hline Validity of the test condition & & Are valid \\
\hline At 5\% significant value & Are valid & Do not reject the null hypothesis \\
\hline CONCLUSION & $\begin{array}{l}\text { BD chosen and AL subject } \\
\text { stream are independent }\end{array}$ & $\begin{array}{l}\text { BD chosen and AL subject } \\
\text { stream are independent }\end{array}$ \\
\hline
\end{tabular}

According to table 4, boys and girls in the year 2012 have used the optionality when selecting their preferred Bachelor's degree except the students followed the science stream.

Table 5 Summary of Pearson Chi-Square test results for the year 2013

\begin{tabular}{lll}
\hline Academic year -2013 & Boys & Girls \\
\hline Sample size - entire data set & 113 & 74 \\
\hline Pearson's Chi-Square value & 5.207 & 20.165 \\
\hline P value & $0.267(26.7 \%)$ & $0.003(0.3 \%)$ \\
\hline $\begin{array}{l}\text { No. of cells (\%) whose expected } \\
\text { count is less than 5 }\end{array}$ & 2 cells $(22.2 \%)$ & 4 cells $(33.3 \%)$ \\
\hline Validity of the test condition & & Not valid \\
\hline Decision taken to continue the analysis & Social Science removed & Arts stream removed \\
\hline Sample size (for refined data set) & 95 & 70 \\
\hline Pearson's Chi-Square value & 1.005 & 6.261 \\
\hline P value & $0.605(60.5 \%)$ & $0.181(18.1 \%)$ \\
\hline $\begin{array}{l}\text { No. of cells }(\%) \text { whose expected } \\
\text { count is less than 5 }\end{array}$ & 0 cells $(0 \%)$ & 1 cell (11.1\%) \\
\hline Validity of the test condition & & Are valid \\
\hline At 5\% significant value & Are valid & Do not reject the null hypothesis \\
\hline
\end{tabular}




\begin{tabular}{lll}
\hline CONCLUSION & $\begin{array}{l}\text { BD chosen and AL subject } \\
\text { stream are independent }\end{array}$ & $\begin{array}{l}\text { BD chosen and AL subject } \\
\text { stream are independent }\end{array}$ \\
\hline
\end{tabular}

The chi-square test results are significantly different for 2014 than other years and the student population also higher than the previous years. The chi-square test results were significant for the entire data set and test of independence implemented without removing any data.

Table 6 Summary of Pearson Chi-Square test results for the year 2014

\begin{tabular}{lll}
\hline Academic year -2014 & Boys & Girls \\
\hline \multicolumn{1}{c}{ Sample size - entire data set } & 130 & 112 \\
\hline Pearson's Chi-Square value & 11.542 & 13.607 \\
\hline P value & $0.073(7.3 \%)$ & $0.034(3.4 \%)$ \\
\hline $\begin{array}{l}\text { No. of cells }(\%) \text { whose expected } \\
\text { count is less than 5 }\end{array}$ & 0 cells $(0 \%)$ & 0 cells $(0 \%)$ \\
\hline Validity of the test condition & & Are valid \\
\hline Decision taken to continue the analysis & Entire data set taken & Entire data set taken \\
\hline At 5\% significant value & Do not reject the null hypothesis & Reject the null hypothesis \\
\hline CONCLUSION & $\begin{array}{l}\text { BD chosen and AL subject } \\
\text { stream are independent }\end{array}$ & $\begin{array}{l}\text { BD chosen and AL subject } \\
\text { stream are not independent }\end{array}$ \\
\hline
\end{tabular}

In conclusion, both boys and girls in the academic year 2012 have selected their respected Bachelor's degree irrespective of the subject stream followed for Advanced level. The results indicated that there is no difference between the girls and boys of 2013 batch in their decision-making criteria because they selected the Bachelor's degree independently without considering their subject stream followed for Advanced level. For 2014, results indicated that there is a significant difference between girls and boys in their selection of Bachelor's degree as girls have selected their Bachelor's degree based on the subject stream followed for Advanced level where it is in the opposite behaviour for boys.

The Chi-square test determined that there is a significant change in using the optionality by boys within the period from 2012-2014 except 2011. Even though boys in 2011 have chosen their Bachelor's degree according to their subject stream at the advanced level, it confirmed by the refined data set. Indeed International degree programme in 2011 was at the emerging stage and boys may be unaware of the characteristics of the International degree programme or they may not have used optionality offered under International degree programmes. Even though girls of the year 2012 and 2013 used optionality when selecting a Bachelor's degree, girls in 2014 considered the subject stream followed for advanced level when selecting the preferred Bachelor's degree.

However, it has noticed that there is an increase in the student population from 2011 to 2014 of the selected private higher educational institutes which indicates the popularity of their Bachelor's degree offers under the International degree programmes. However, girls in 2011 enrolled for the Bachelor's degree independently from their advanced level subject stream that may be due to the experience of the subjects in the advanced level stream. Alternatively, girls with the Advanced level qualification in mathematics and commerce stream show different attitudes towards the Bachelor's degree selection where they prioritized the optionality. The different behaviour of girls in 2011 may be due to the emerging stage of International degree programmes and students may feel it is risky to use the optionality to select different discipline without prerequisite knowledge.

\section{Conclusion}


International degree programmes have emerged as an alternative option for Sri Lankan students to pursue a Bachelor's degree to cater to the demands in the society, and it offers Bachelor's degrees with high optionality and flexibility. Further, most of the International degree programmes offer industry demand courses and, they are designed to deliver the basic knowledge for students during the first year. Thereby students in any subject stream are facilitated to enroll for the preferred Bachelor's degree in International degree programme when the minimum requirement has reached. The results indicated that the association between the subject stream followed in Advanced level and the type of Bachelor's degree selected from the International degree programme from 2011 to 2014 are different among girls and boys. Furthermore, the study confirmed that there is a positive trend in using the available optionality in International degree programmes by boys and negative attitude by girls than at the emerging level.

\section{Recommendations}

As this is the initial attempt to identify the popularity of the optionality offer in the International degree programmes, it is recommended to conduct the test of association for recent years to uncover any different behaviour in using the optionality among boys and girls. Additionally, to extend the research study for several private higher educational institutes who conduct different International degree programmes and to compare any differences in students' choice behaviour. Finally, to identify any gender impact on the influential factors in selecting a Bachelor's degree from International degree programmes.

\section{References}

Abeygunawardena, K. A. V., 2018, Influential Factors in Selecting a Bachelor's Degree from Private Higher Educational Institutes in Sri Lanka: A Study Based on Undergraduates of International Degree Programmes. PEOPLE: International Journal of Social Sciences, 4(2), 75-96. Retrieved from https://dx.doi.org/10.20319/pijss.2018.42.7596.

Abeygunawardena, K. A. V., 2019, Students' Behavioural Patterns on Bachelor's Degree Choices in Sri Lanka: Heuristics?. PEOPLE: International Journal of Social Sciences, 4(3), 763-785. Retrieved from https://dx.doi.org/10.20319/pijss.2019.43.763785.

Bandura, A., 1986, Social foundations of thought and action: A social cognitive theory (Englewood, Cliffs.: Prentice-Hall).

Briggs, S., 2006, An exploratory study of the factors influencing undergraduate student choice: the case of higher education in Scotland. Studies in Higher Education, 31(6), 705-722.

Cannon-Bowers, JA., Salas, E., and Pruitt, JS., 1996, Establishing the boundaries of a paradigm for decision making research. Human Factors, 38, 193-205.

Clark, A. C., and Wiebe, E. N., 1993, Comparing computer usage by students in education programs to technology education majors. Journal of Technology Education, 13(1), 5-16.

Daily mirror. (2017, February 27). Non-state actors in higher education in Sri Lanka: Issue and challenges. Retrived from http://www.dailymirror.lk/article/Non-state-actors-in-higher-education-in-Sri-Lanka-Issues-andchallenges-124528.html.

Fernandez, J. L., 2010, An exploratory study of factors influencing the decision of students to study at University Sains Malaysia. Kajian Malaysia, 28(2), 107-136.

Halpern, DE., 1997, Critical thinking across the curriculum (Mahwah, NJ.: Erlbaum).

Hamrick, F. A., and Hossler, D., 1996, Diverse information gathering methods in the postsecondary decision making process. Review of Higher Education, 19(2), 179-198.

Hearn, J., 1984, The relative roles of academic ascribed and socioeconomic characteristics in college destinations. Sociology of Education, 57, 22-30.

Hossler, D., Schmit, J., and Vesper, N., 1999, Going to College: How Social, Economic, and Educational Factors Influence the Decisions Students Make (Baltimore.: The Johns Hopkins University Press).

Jackson, G., 1978, Financial aid and student enrollment. Journal of Higher Education, 49, 548-74. 
Knight J., 2007, Internationalization: Concepts, Complexities and Challenges. In: Forest J.J.F., Altbach P.G. (eds) International Handbook of Higher Education. Springer International Handbooks of Education, vol 18. Springer, Dordrecht..

Knight, J., 2012, Student mobility and internationalisation: Trends and tribulations. Research in Comparative and International Education, 7, 20-33.

Maria, L. L., Maria, T. S. A. B., and Maria, C. E., 2007, Factors that affect decision making: Gender and Age differences. USA. International Journal of Psychology and Psychological Therapy, 7 (3), 381-391.

McDonough, P. M., 1997, Choosing Colleges: How Social Class and Schools Structure Opportunity (Albany, New York.: State University of New York Press).

Narayan, SM., and Corcoran-Perry, S., 1997, Line of reasoning as a representation of nurses' clinical decision making. Research in Nursing \& Health, 20, 353-364.

Orasanu, J., and Connolly, T., 1993, The reinvention of decision making. In: G Klein, J Orasanu, R Calderwood \& CE Zsambok (Eds.), Decision making in action: Models and methods, edited by Riggle EDB and Johnson MMS, (Norwood, NJ: Ablex), pp. 3- 20.

Ozga, J., and Sukhnandan, L., 1997, Undergraduate Non-Completion, Higher Education Funding Council for England Report 97/29 Report 2 (Bristol, HEFCE).

Pagliarulo, G. M., 2004, The influence of parental involvement on the educational aspirations of first-generation college students. (Order No. 1419454, University of Maryland, College Park). ProQuest Dissertations and Theses, 124-124 p. Retrieved from http://search.proquest.com/docview/305176007?accountid=40667. (prod.academic_MSTAR_305176007).

Poo, B. T., Ismail, R., Sulaiman, N., and Othman, N., 2012. Globalization and the factors influencing households' demand for Higher Education in Malaysia. International Journal of Education and Information Technologies, 3(6), 269-278.

Somers, P., Haines, K., and Keene, B., 2006, Toward a theory of choice for community college students. College Journal of Research and Practice, 20, 53-67.

Sunday Times. (2011, June Sunday). University entrance for London AL students in Sri Lanka. EducationArchives. Colombo,Sri Lanka.

Tierney, M. L., 1983, Student college choice sets: Toward an empirical characterization. Research in Higher Education, 18(3), 271-284.

University Grants Commission - Sri Lanka : Website : www.ugc.ac.1.

Yates, D., Moore, D., and McCabe, G., 1999, The Practice of Statistics (New York.: Freeman).

Yorke, M., 1999. Leaving early: undergraduate non-completion in higher education (London.: Falmer). 